\title{
Interference-Free Determination of Trace Copper in Freshly Ripened Honeys by Flame Atomic Absorption Spectrometry Following a Preconcentration by Solid-Phase Extraction and a Two-Step Elution Process
}

\author{
Pawel Pohl $\cdot$ Helena Stecka $\cdot$ Piotr Jamroz
}

Received: 17 August 2013/Accepted: 9 October 2013/Published online: 29 October 2013

(C) The Author(s) 2013. This article is published with open access at Springerlink.com

\begin{abstract}
A fast and straightforward procedure aimed at separating copper $(\mathrm{Cu})$ ions from monosacharides and preconcentrating their traces before flame atomic absorption spectrometry (FAAS) measurements was developed, and its suitability was evaluated by the analysis of freshly ripened honeys on the content of this environmentally and physiologically relevant element. This procedure included the passage (at $20 \mathrm{~mL} / \mathrm{min}$ ) of $10 \%(\mathrm{~m} / \mathrm{v})$ solutions of honeys $(100 \mathrm{~mL})$ through resin beds of Dowex $50 \mathrm{~W} \times 8$ 400 to retain $\mathrm{Cu}$ by solid-phase extraction (SPE) and separate it from the glucose and fructose matrix. In turn, SPE columns were rinsed at $20 \mathrm{~mL} / \mathrm{min}$ with $20 \mathrm{~mL}$ of water and subsequently washed with $20 \mathrm{~mL}$ of a $0.5 \mathrm{~mol} / \mathrm{L}$ $\mathrm{HNO}_{3}$ solution (at $2.0 \mathrm{~mL} / \mathrm{min}$ ) to elute potassium and sodium. Preconcentrated $\mathrm{Cu}$ was stripped (at $2.0 \mathrm{~mL} / \mathrm{min}$ ) with $5.0 \mathrm{~mL}$ of a $2.0 \mathrm{~mol} / \mathrm{L} \mathrm{HCl}$ solution and determined by FAAS. The proposed procedure was used for the analysis of six ripened monoflower and multiflower honeys, enabling the measurement of $\mathrm{Cu}$ within the range of $0.17-0.42 \mu \mathrm{g} / \mathrm{g}$ and with a precision of 3-10\%. Recoveries of $\mathrm{Cu}$ added to respective honey solutions were within 94-102\%, proving the good accuracy of this procedure. The detection limit of $\mathrm{Cu}$ achieved with this SPE preconcentration/separation procedure and FAAS detection was $3.6 \mathrm{ng} / \mathrm{g}$.
\end{abstract}

Ripened honeys exhibit a great variability in the content of copper $(\mathrm{Cu})$ mostly due to (1) their floral and regional variations and (2) the different kinds of environmental

P. Pohl $(\bowtie) \cdot$ H. Stecka · P. Jamroz

Division of Analytical Chemistry, Faculty of Chemistry,

Wroclaw University of Technology, 50-370 Wrocław, Poland

e-mail: pawel.pohl@pwr.wroc.pl pollutions that contaminate them (Bogdanov 2006; Pohl 2009). This can be seen from Table 1, where the data for honeys from different countries are listed and vary from levels lower than the detection limit to $34 \mu \mathrm{g} / \mathrm{g}$; however, most commonly the concentration of $\mathrm{Cu}$ is approximately $1 \mu \mathrm{g} / \mathrm{g}$. An additional source of contamination of honey with $\mathrm{Cu}$ could be beekeeping practices and honey processing after harvesting (Pohl 2009). Steel and galvanized tools and containers used for the honey harvesting, ripening, and packing quite commonly undergo corrosion in contact with the honey, and this results in the release of simple ions of $\mathrm{Cu}$ and other related elements (chromium, iron [Fe], nickel) (Paramas et al. 2000).

The intake of high amounts of $\mathrm{Cu}$ with dietary products can be manifested by various malfunctions in the nervous system and the formation of reactive oxygen species, which lead to severe oxidative damages and dysfunctions of almost all biological cell molecules, including lipids, proteins, and nucleic acids (Bremner 1998; Gaetke and Chow 2003). Given the necessity of a fast and straightforward evaluation of honey safety and quality in reference to its contents of toxic trace $\mathrm{Cu}$ and other related elements, it could be reasonably argued that analytical methods enabling such reliable determinations in honey would be highly important and desirable.

Flame atomic absorption spectrometry (FAAS) with an airacetylene flame is a well-established element specific detection technique commonly used for the analysis of honey as to the content of $\mathrm{Cu}$ and other trace elements (Pohl 2009; Pohl et al. 2009). Unfortunately, organic (glucose and fructose mostly) and inorganic (cationic and anionic minerals, such as chlorine, potassium $[\mathrm{K}]$, sodium $[\mathrm{Na}]$, and phosphorous) constituents of the honey matrix are often responsible for different kind of spectral and nonspectral interferences that accompany FAAS measurements (Hernandez et al. 2005; dos 
Table 1 Concentration ranges of $\mathrm{Cu}$ measured in monofloral and multifloral honeys of the different origin measured using FAAS

\begin{tabular}{|c|c|c|}
\hline Country & $\begin{array}{l}\text { Concentration } \\
(\mu \mathrm{g} / \mathrm{g})\end{array}$ & Reference \\
\hline Argentina & $\mathrm{ND}$ & Baroni et al. (2009) \\
\hline Brazil & ND-33.77 & dos Santos et al. (2008) \\
\hline Czech & $0.11-1.50$ & $\begin{array}{l}\text { Vorlova and Celechovska (2002), } \\
\text { Lachman et al. (2007) }\end{array}$ \\
\hline India & $1.29-2.90$ & Nanda et al. $(2003,2009)$ \\
\hline Pakistan & $0.12-0.91$ & Khan et al. (2006) \\
\hline Poland & ND-1.82 & $\begin{array}{l}\text { Wieczorek et al. (2006), Madejczyk and } \\
\text { Baralkiewicz (2008), Juszczak et al. } \\
\text { (2009), Pohl and Sergiel (2010, } \\
\text { 2012), Grembecka and Szefer (2013) }\end{array}$ \\
\hline $\begin{array}{l}\text { Saudi } \\
\text { Arabia }\end{array}$ & $0.21-0.39$ & Osman et al. (2007) \\
\hline Spain & $0.04-1.73$ & $\begin{array}{l}\text { Latorre et al. (1999); Hernandez et al. } \\
\text { (2005) }\end{array}$ \\
\hline Turkey & ND-3.50 & $\begin{array}{l}\text { Uren et al. (1998); Yilmaz and Yavuz } \\
\text { 1999; Erbilir and Erdogrul 2005; } \\
\text { Turhan (2007) }\end{array}$ \\
\hline
\end{tabular}

$N D$ not detected

Santos et al. 2008; Pohl et al. 2012a, b). For that reason, analyzed samples of honey are mineralized before determinations by FAAS to simplify the sample matrix and eliminate related matrix effects. Apparently, from the literature, honeys are dry ashed in a number of cases (Uren et al. 1998; Latorre et al. 1999; Yilmaz and Yavuz 1999; Vorlova and Celechovska 2002; Erbilir and Erdogrul 2005; Wieczorek et al. 2006; Lachman et al. 2007; Osman et al. 2007) by hightemperature incinerations of relatively high sample masses (5-20 g). The resulting ashes are evaporated in the presence of added $\mathrm{HCl}$ or $\mathrm{HNO}_{3}$ solutions and subsequently reconstituted with water to transfer all inorganic components into sample solutions. Wet ashing in a concentrated solution of $\mathrm{HNO}_{3}$, or its combination with concentrated solutions of $\mathrm{H}_{2} \mathrm{SO}_{4}$ or $\mathrm{HClO}_{4}$, is also applied and realized in open- (Nanda et al. 2003; Rashed and Soltan 2004) or closed- (Madejczyk and Baralkiewicz 2008) vessel systems. Both digestion approaches certainly enable the decomposition of the carbohydrate-rich honey matrix and release simple ions through which nonspectral and spectral interferences affecting the sample solution introduction, in addition to dissociation and atomization processes in the air-acetylene flame, respectively, are eliminated (Uren et al. 1998; Lachman et al. 2007; dos Santos et al. 2008). Unfortunately, using this manner of sample preparation, many problems may be encountered during the analysis of honey by FAAS. Apparently, dry ashing is laborious, and it takes a long time to prepare suitable sample solutions before measurements. A risk of losses of trace elements (including $\mathrm{Cu}$ among others) due to volatilization is quite high and frequent with this method (Zukowska and
Biziuk 2008). When using wet-ashing procedures, only small amounts of samples are commonly handled at once; hence, trace elements, such as $\mathrm{Cu}$, might not be detected at sufficiently low levels.

Methods of direct and nondestructive analysis of honey as to the content of $\mathrm{Cu}$ and other environmentally, toxicologically, and nutritionally relevant trace elements, such as the simple dissolution of samples in water and measurements of resulting solutions or other faster and less laborious approaches, are quite uncommon (Hernandez et al. 2005; dos Santos et al. 2008). It seems reasonable to suppose that alternative approaches to drastic oxidative treatments with continued heating of honey samples would be both needed and desired to simplify and shorten the analysis using FAAS. With respect to this problem, a possibility of the direct determination of $\mathrm{Cu}$ in solutions of honey subjected to a solid-phase extraction (SPE)-based preconcentration/separation procedure was verified. To retain traces of $\mathrm{Cu}$ and the separate aforementioned monosaccharides, the sorption behavior of a gel-type strong acidic cation exchanger Dowex $50 \mathrm{~W} \times 8-400$ was examined. Then conditions of the two-step elution, first removing $\mathrm{K}$ and $\mathrm{Na}$ ions from honey's resin beds and then recovering enriched $\mathrm{Cu}$ traces, was optimized. The analytical performance of the developed SPE preconcentration/separation procedure was evaluated and the method was applied to the analysis of freshly ripened monoflower and multiflower honeys as to their content of $\mathrm{Cu}$.

\section{Materials and Methods}

\section{Instrumentation}

All measurements of element concentrations were performed with a Perkin Elmer (Waltham, MA, USA) singlebeam atomic absorption spectrometer model 1100B. This instrument is equipped with a laminar-flow burnerincluding an end cup with a drain interlock assemblage, a flow spoiler, a burning mixing chamber, and a single-slot burner head-for a very sharp air-acetylene-lean flame. A stainless steel nebulizer was used to aspirate all solutions. Measurements of $\mathrm{Cu}$ concentrations were made in an absorption mode (FAAS); $\mathrm{K}$ and $\mathrm{Na}$ were measured using the instrument operated in an emission mode [flame optical emission spectrometry (FOES)]. Readings of absorbance and emission intensities were performed using time-average integration. In each read cycle, three readings were integrated at 0.1-second intervals during a 3 -second integration time and averaged. All instrumental settings recommended by the manufacturer were used for measurements of $\mathrm{Cu}$ by FAAS and $\mathrm{K}$ and $\mathrm{Na}$ by FOES. Instrumental detection limits for $\mathrm{Cu}, \mathrm{K}$, and $\mathrm{Na}$, based on 
$3 \times$ SD of average $(n=5)$ intensities for a water blank, were $6.8,0.4$, and $1.1 \mu \mathrm{g} / \mathrm{L}$, respectively. The precision of the determination of $\mathrm{Cu}, \mathrm{K}$, and $\mathrm{Na}$ concentrations, as relative SDs of average measurements $(n=3)$ of 0.05 , 0.10 , and $0.20 \mathrm{mg} / \mathrm{L}(\mathrm{Cu})$ and $0.02,0.05$ and $0.10 \mathrm{mg} / \mathrm{L}(\mathrm{K}$, $\mathrm{Na}$, were in the range $1.7-6.3,1.4-5.6$ and $2.1-6.7 \%$, respectively.

A Thermo Scientific (Bremen, Germany) single-beam Spectronic 20D+ digital visible spectrophotometer was applied for determining the sum of concentrations of fructose and glucose by the Somogyi-Nelson (arsenomolybdate) method (Fournier 2005). To measure concentrations of both monosaccharides, $10 \mu \mathrm{L}$ of analyzed sample solutions were incubated at $90{ }^{\circ} \mathrm{C}$ for $10 \mathrm{~min}$ with addition of $0.5 \mathrm{~mL}$ of a $6.0 \mathrm{~g} / \mathrm{L}$ alkaline $\mathrm{CuSO}_{4}$ solution. After cooling, $1.0 \mathrm{~mL}$ of an arseno-molybdate reagent solution, which was obtained by mixing a $50 \mathrm{~g} / \mathrm{L}$ $\left(\mathrm{NH}_{4}\right)_{6} \mathrm{Mo}_{7} \mathrm{O}_{24}$ solution with a $6.0 \mathrm{~g} / \mathrm{L} \mathrm{Na} 2 \mathrm{HAsO}_{4}$ solution in the presence of a $0.78 \mathrm{~mol} / \mathrm{L} \mathrm{H}_{2} \mathrm{SO}_{4}$ solution, was added to resulting reaction mixtures and vigorously shaken. After 10 more minutes, they were diluted to $10.0 \mathrm{~mL}$ and remixed. Finally, absorbances related to a polymolybdate complex of intensive blue color produced in these solutions were measured spectrophotometrically at $520 \mathrm{~nm}$. Sums of concentrations of fructose and glucose were determined against an appropriate reagent blank and standard working solutions containing from 1 to $50 \mathrm{mg} / \mathrm{L}$ of glucose.

\section{Reagents and Materials}

Highly pure water produced by a WIGO (Wroclaw, Poland) PRO-11G reverse osmosis water purification system was used throughout. Solutions of ACS grade concentrated reagents, i.e., $30 \%(\mathrm{~m} / \mathrm{m}) \mathrm{H}_{2} \mathrm{O}_{2}, 37 \%(\mathrm{~m} / \mathrm{m})$ $\mathrm{HCl}, 65 \%(\mathrm{~m} / \mathrm{m}) \mathrm{HNO}_{3}$, and $95-98 \%(\mathrm{~m} / \mathrm{m}) \mathrm{H}_{2} \mathrm{SO}_{4}$, were supplied by J. T. Baker (Deventer, Netherlands). Other reagents-including D-fructose (purity $>98 \%$ ), D-glucose (purity $>98 \%$ ), $\mathrm{CuSO}_{4} \cdot 5 \mathrm{H}_{2} \mathrm{O},\left(\mathrm{NH}_{4}\right)_{6} \mathrm{Mo}_{7} \mathrm{O}_{24} \cdot 4 \mathrm{H}_{2} \mathrm{O}$, and $\mathrm{Na}_{2} \mathrm{HAsO}_{4} \cdot 7 \mathrm{H}_{2} \mathrm{O}$-were of analytical reagent grade and purchased from POCH (Gliwice, Poland). Merck KGaA (Darmstadt, Germany) Titrisol single-element standards for AAS containing $1,000 \mathrm{mg}$ of $\mathrm{Cu}$ (as $\mathrm{CuCl}_{2}$ in water), $\mathrm{K}$ (as $\mathrm{KCl}$ in water), and $\mathrm{Na}$ (as $\mathrm{NaCl}$ in water) were used to prepare $1,000 \mathrm{mg} / \mathrm{L}$ single-element stock standard solutions of these elements.

Working standard solutions of $\mathrm{Cu}, \mathrm{K}$, and $\mathrm{Na}$ for calibration of the spectrometer and $100-\mathrm{mL}$ working standard solutions containing $0.2,20$, and $5.0 \mathrm{mg} / \mathrm{L}$ of $\mathrm{Cu}, \mathrm{K}$, and $\mathrm{Na}$ with admixture of fructose and glucose at concentrations of $40 \mathrm{~g} / \mathrm{L}$ were prepared by diluting appropriate bulk standard solutions and adding appropriate amounts of solid monosaccharides. The latter solutions were applied to investigate sorption and desorption conditions of the cation exchangers used for SPE. Their composition corresponded to typical concentrations of $\mathrm{K}$ and $\mathrm{Na}$ as well as predominating fructose and glucose in $10 \%(\mathrm{~m} / \mathrm{v})$ water solutions of monofloral and multifloral Polish honeys (Madejczyk and Baralkiewicz 2008; Chudzinska and Baralkiewicz 2010). In addition, these solutions were adjusted to $\mathrm{pH} 3.5$, 4.0 , and 4.5 , respectively, using a $0.010 \mathrm{~mol} / \mathrm{L} \mathrm{HCl}$ solution.

Calibration curves for FAAS $(\mathrm{Cu})$ and FOES (K and $\mathrm{Na})$ measurements were based on six standard solutions of $\mathrm{Cu}$ $(0.05-1.00 \mathrm{mg} / \mathrm{L}), \quad \mathrm{K} \quad(0.01-1.00 \mathrm{mg} / \mathrm{L}), \quad$ and $\mathrm{Na}$ $(0.01-1.00 \mathrm{mg} / \mathrm{L})$. For the determination of $\mathrm{K}$ and $\mathrm{Na}$, simple water standard solutions were only used. For the quantification of $\mathrm{Cu}$, simple water standard solutions were used, and two additional sets of matrix matching standard solutions were prepared as well. The first set of standard solutions contained $40 \mathrm{~g} / \mathrm{L}$ of fructose and glucose and was used for the evaluation of sorption properties of the resin. The second set of standard solutions contained adequate portions of $\mathrm{HCl}$ depending on the elution solution applied at the desorption step.

The strongly acidic cation exchange styrene-divinylbenzene resin Dowex $50 \mathrm{~W} \times 8-400$ with sulphonic acid functional groups (particle size $38-75 \mu \mathrm{m}, \mathrm{H}^{+}$form) was provided by Sigma-Aldrich (Saint Louis, MO, USA). The resin was packed into Sigma-Aldrich glass columns (1.0$\mathrm{cm}$ inner diameter) with glass coarse frits and polytetrafluoroethylene stopcocks. Flow rates of all solutions loaded onto SPE columns and passed through resin beds of Dowex $50 \mathrm{~W} \times 8-400$ were controlled using Cole-Parmer (Vernon Hill, Illinois, USA) four-channel MasterFlex L/S peristaltic pumps.

SPE columns were filled with slurries of water-cleaned $1.0 \mathrm{-g}$ portions of the resin suspended in water. Resin beds formed were flushed with $20 \mathrm{~mL}$ of water and then conditioned with $10 \mathrm{~mL}$ of a $2.0 \mathrm{~mol} / \mathrm{L} \mathrm{HCl}$ solution at $5.0 \mathrm{~mL} / \mathrm{min}$. Finally, columns were rinsed at the same flow rate with $50 \mathrm{~mL}$ of water to remove excess $\mathrm{HCl}$.

\section{Honey Samples and Their Preparation}

Ripened honeys-including acacia, heather, goldenrod, lime, multiflower and rape-were taken from an apiary located in suburbs of Wroclaw (Lower Silesian Province, Poland). Honeys were kept in a laboratory (at room temperature and in a dark place) in the original glass jars in which they were dispatched. Before sampling, contents of jars were vigorously stirred with a glass stirring bar to homogenize analyzed subsamples.

For wet ashing of honey samples, their representative 2.5 -g portions were placed in $250-\mathrm{mL}$ beakers covered with watch glasses, dissolved in $10 \mathrm{~mL}$ of water, and treated with $10 \mathrm{~mL}$ of a concentrated $\mathrm{HNO}_{3}$ solution. Samples 
Fig. 1 A schematic diagram of the SPE based preconcentration/ separation procedure
I. Sample loading

$100 \mathrm{~mL}$ of a $10 \%$ honey solution at $20 \mathrm{~mL} / \mathrm{min}$

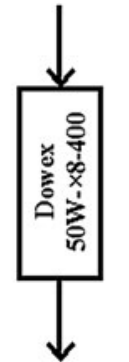

were refluxed at $80-90{ }^{\circ} \mathrm{C}$ for approximately $2.5-3.0 \mathrm{~h}$ to avoid spattering and boiling. After cooling, remained digests $(1-2 \mathrm{~mL})$ were treated with $10 \mathrm{~mL}$ of a $30 \%(\mathrm{~m} /$ m) $\mathrm{H}_{2} \mathrm{O}_{2}$ solution. Heating was prolonged for $1 \mathrm{~h}$ to decompose added $\mathrm{H}_{2} \mathrm{O}_{2}$ and decrease volumes of digested samples to approximately 1 to $2 \mathrm{~mL}$. Resulting solutions were finally brought to $50 \mathrm{~mL}$ with water. The total time investment in this procedure was approximately $4 \mathrm{~h}$.

For an SPE-based preconcentration/separation procedure with subsequent two-step elution, representative $10-\mathrm{g}$ samples of analyzed honeys were placed in $250-\mathrm{mL}$ beakers, dissolved at first in $10 \mathrm{~mL}$ of water, and then brought to $100 \mathrm{~mL}$. Resulting $10 \%(\mathrm{~m} / \mathrm{v})$ honey solutions were passed at $20 \mathrm{~mL} / \mathrm{min}$ through SPE columns filled with $1.0 \mathrm{~g}$ of Dowex $50 \mathrm{~W} \times 8-400$ to retain $\mathrm{Cu}(\mathrm{II})$ ions and separate them from monosaccharides and anionic minerals. After sample loading, SPE columns were rinsed with $10 \mathrm{~mL}$ of water at $20 \mathrm{~mL} / \mathrm{min}$, and $20 \mathrm{~mL}$ of a $0.5 \mathrm{~mol} / \mathrm{L}$ $\mathrm{HNO}_{3}$ solution was subsequently passed through them at $2.0 \mathrm{~mL} / \mathrm{min}$ to remove matrix elements $\mathrm{K}$ and $\mathrm{Na}$. At the end, $5.0 \mathrm{~mL}$ of a $2.0 \mathrm{~mol} / \mathrm{L} \mathrm{HCl}$ solution was used to elute $\mathrm{Cu}$ (II) before measurements of its concentrations by FAAS versus matrix matching standard solutions (see Fig. 1). The total time investment in this procedure was approximately three quarters of an hour including preparations of resin beds and sample solutions.

For both sample preparation procedures, analyses were made on three parallel samples. Respective procedural blanks were prepared and considered in final results given as average values with standard uncertainties.

\section{Results and Discussion}

Sorption Behavior of Dowex $50 \mathrm{~W} \times 8-400$

The sorption behavior of $\mathrm{Cu}(\mathrm{II}), \mathrm{K}(\mathrm{I})$, and $\mathrm{Na}(\mathrm{I})$ ions, in addition to that of fructose and glucose, was examined

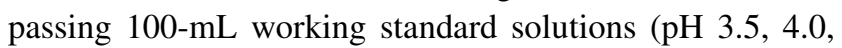
and 4.5 ) at $2.0 \mathrm{~mL} / \mathrm{min}$ through SPE columns filled with
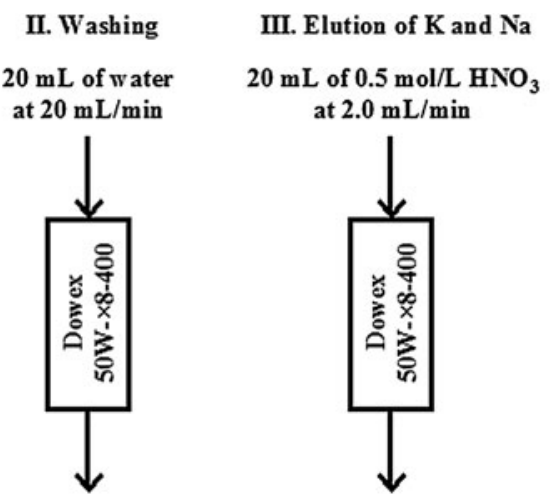

IV. Elution of $\mathrm{Cu}$

$5.0 \mathrm{~mL}$ of $2.0 \mathrm{~mol} / \mathrm{L} \mathrm{HCl}$ at $2.0 \mathrm{~mL} / \mathrm{min}$

Table 2 Retention (for $\mathrm{Cu}, \mathrm{K}$ and $\mathrm{Na}$ ) and separation (for fructose with glucose) efficiencies (in $\%$ ) achievable with Dowex $50 \mathrm{~W} \times 8$ 400 at $\mathrm{pH} 3.5-4.5$

\begin{tabular}{llrlc}
\hline $\mathrm{PH}$ & $\mathrm{Cu}$ & \multicolumn{1}{l}{$\mathrm{K}$} & $\mathrm{Na}$ & Monosaccharides $^{\mathrm{b}}$ \\
\hline 3.5 & $>97.0^{\mathrm{a}}$ & $99.9 \pm 0.1$ & $100.0 \pm 0.1$ & $101.4 \pm 1.8$ \\
4.0 & $>97.0^{\mathrm{a}}$ & $99.9 \pm 0.1$ & $100.0 \pm 0.1$ & $99.1 \pm 7.8$ \\
4.5 & $>97.0^{\mathrm{a}}$ & $100.0 \pm 0.1$ & $100.0 \pm 0.1$ & $95.2 \pm 6.1$ \\
\hline
\end{tabular}

Average values $(n=3) \pm$ SDs

${ }^{\text {a }}$ Concentrations of $\mathrm{Cu}$ in effluents are lower than the respective DL

b Sum of concentrations of fructose and glucose

the resin studied. $10 \mathrm{~mL}$ portions of the resulting effluents collected at the end of the solution loading were next analyzed by FAAS and FOES for the contents of $\mathrm{Cu}$ and $\mathrm{K}$ with $\mathrm{Na}$, respectively, which were not retained by the resin. Matrix matching standard solutions containing $40 \mathrm{~g} / \mathrm{L}$ of fructose and glucose were used for calibration in this case. Sums of concentrations of fructose and glucose were measured using the Somogyi-Nelson spectrophotometric method. Concentrations of $\mathrm{Cu}, \mathrm{K}$, and $\mathrm{Na}$ retained on resin beds under given conditions were evaluated by subtracting concentrations of these elements determined in portions of effluents collected from their initial concentrations in working standard solutions. Retention efficiencies for $\mathrm{Cu}$, $\mathrm{K}$, and $\mathrm{Na}$ (in \%) were assessed by relating concentrations of retained elements to their original concentrations in loaded working standard solutions. Separation efficiencies (in \%) for fructose and glucose were evaluated by relating concentrations of both monosaccharides found in aforementioned portions of effluents to their initial concentrations in loaded working standard solutions.

It was established that Dowex $50 \mathrm{~W} \times 8-400$ quantitatively retains $\mathrm{Cu}$ (II) ions from solutions containing fructose and glucose (Table 2). Apparently all effluents collected were found to contain $\mathrm{Cu}$ at concentrations lower than the respective detection limit (DL) of $\mathrm{Cu}$ obtained by FAAS. Fructose and glucose were established to pass through beds of the resin completely unretained. In respect to this, it 
Table 3 Elution efficiencies (in \%) of $\mathrm{Cu}, \mathrm{K}$, and $\mathrm{Na}$ from resin beds of the strong cation exchange resin Dowex $50 \mathrm{~W} \times 8-400$ obtained using 0.2 and $0.5 \mathrm{~mol} / \mathrm{L} \mathrm{HNO}_{3}$ and $\mathrm{HCl}$ solutions

\begin{tabular}{|c|c|c|c|c|c|c|c|c|c|c|c|c|c|}
\hline \multicolumn{4}{|l|}{$\mathrm{Cu}$} & \multicolumn{5}{|l|}{$\mathrm{K}$} & \multicolumn{5}{|l|}{$\mathrm{Na}$} \\
\hline I & II & III & IV & I & II & III & IV & Sum & I & II & III & IV & Sum \\
\hline \multicolumn{14}{|c|}{$0.2 \mathrm{~mol} / \mathrm{L} \mathrm{HNO}_{3}$} \\
\hline$<0.3^{\mathrm{a}}$ & $<0.3^{\mathrm{a}}$ & $<0.3^{\mathrm{a}}$ & $\begin{array}{l}0.6 \\
(0.3)\end{array}$ & $\begin{array}{l}0.5 \\
(0.3)\end{array}$ & $\begin{array}{l}7.1 \\
(3.6)\end{array}$ & $\begin{array}{l}34.5 \\
\quad(5.7)\end{array}$ & $\begin{array}{l}25.6 \\
(6.0)\end{array}$ & $\begin{array}{l}67.7 \\
\quad(9.0)\end{array}$ & $\begin{array}{l}28.2 \\
\quad(5.8)\end{array}$ & $\begin{array}{l}57.7 \\
(5.0)\end{array}$ & $\begin{array}{l}16.1 \\
(9.1)\end{array}$ & $\begin{array}{l}1.0 \\
(0.6)\end{array}$ & $\begin{array}{c}103.0 \\
(11.9)\end{array}$ \\
\hline \multicolumn{14}{|c|}{$0.5 \mathrm{~mol} / \mathrm{L} \mathrm{HNO}_{3}$} \\
\hline$<0.3^{\mathrm{a}}$ & $<0.3^{\mathrm{a}}$ & $\begin{array}{l}0.7 \\
\quad(0.3)\end{array}$ & $\begin{array}{l}1.2 \\
(0.4)\end{array}$ & $\begin{array}{l}42.0 \\
(1.3)\end{array}$ & $\begin{array}{l}53.5 \\
(3.5)\end{array}$ & $\begin{array}{l}9.3 \\
(4.5)\end{array}$ & $\begin{array}{l}0.6 \\
(0.2)\end{array}$ & $\begin{array}{r}105.4 \\
(5.9)\end{array}$ & $\begin{array}{l}90.5 \\
(1.6)\end{array}$ & $\begin{array}{l}7.4 \\
(4.3)\end{array}$ & $\begin{array}{l}1.5 \\
(1.1)\end{array}$ & $\begin{array}{l}0.3 \\
(0.1)\end{array}$ & $99.7(4.7)$ \\
\hline \multicolumn{14}{|c|}{$0.2 \mathrm{~mol} / \mathrm{L} \mathrm{HCl}$} \\
\hline$<0.3^{\mathrm{a}}$ & $\begin{array}{l}0.4 \\
\quad(0.1)\end{array}$ & $\begin{array}{l}0.8 \\
(0.1)\end{array}$ & $\begin{array}{l}1.2 \\
(0.1)\end{array}$ & $\begin{array}{l}0.1 \\
\quad(0.1)\end{array}$ & $\begin{array}{l}1.1 \\
(0.5)\end{array}$ & $\begin{array}{l}5.0 \\
(2.4)\end{array}$ & $\begin{array}{l}24.4 \\
\quad(1.8)\end{array}$ & $\begin{array}{l}30.6 \\
(3.2)\end{array}$ & $\begin{array}{l}1.7 \\
(0.1)\end{array}$ & $\begin{array}{l}72.6 \\
(2.3)\end{array}$ & $\begin{array}{l}23.7 \\
(1.9)\end{array}$ & $\begin{array}{l}0.5 \\
(0.4)\end{array}$ & $98.5(3.0)$ \\
\hline \multicolumn{14}{|c|}{$0.5 \mathrm{~mol} / \mathrm{L} \mathrm{HCl}$} \\
\hline$<0.3^{\mathrm{a}}$ & $\begin{array}{l}0.7 \\
(0.3)\end{array}$ & $\begin{array}{l}1.5 \\
(0.1)\end{array}$ & $\begin{array}{l}3.2 \\
(0.4)\end{array}$ & $\begin{array}{l}5.1 \\
(0.4)\end{array}$ & $\begin{array}{l}87.4 \\
(4.1)\end{array}$ & $\begin{array}{l}6.6 \\
(1.7)\end{array}$ & $\begin{array}{l}1.3 \\
(0.5)\end{array}$ & $\begin{array}{c}100.4 \\
(4.5)\end{array}$ & $\begin{array}{l}97.9 \\
(6.0)\end{array}$ & $\begin{array}{l}4.5 \\
(0.9)\end{array}$ & $\begin{array}{l}1.2 \\
(0.1)\end{array}$ & $\begin{array}{l}1.3 \\
(0.8)\end{array}$ & $\begin{array}{r}104.9 \\
(6.1)\end{array}$ \\
\hline
\end{tabular}

Four 10-mL portions (I through IV) of eluting solutions were passed through resin beds

Average values $(n=3)$ with SDs in parentheses

${ }^{\text {a }}$ Concentrations of $\mathrm{Cu}$ in effluents are lower than the respective DL

seems that $\mathrm{Cu}$ can be adequately preconcentrated before determination of its concentrations by FAAS without matrix effects originating from fructose and glucose. Unfortunately, it was ascertained that the resin has a high capacity for $\mathrm{K}$ and $\mathrm{Na}$ ions as well, which present in working standard solutions at concentrations, respectively, 100 and 25 times greater than the concentration of $\mathrm{Cu}$, were also quantitatively retained in the studied $\mathrm{pH}$ range of 3.5-4.5.

The influence of the flow rate with which working standard solutions were passed through SPE columns on the retention of elements and the separation of fructose and glucose was examined in the range from 2.0 to $20 \mathrm{~mL} / \mathrm{min}$. Selected working standard solutions $(\mathrm{pH} 4.0)$ were passed through SPE columns filled with the Dowex $50 \mathrm{~W} \times 8$ 400 resin, whereas effluents were collected during the passage of these solutions through columns and analyzed to evaluate respective retention and separation efficiencies (average values, $n=3$ ).

It was found that in all cases, concentrations of $\mathrm{Cu}$ determined using FAAS in all collected column effluents were found to be lower than the respective DL, whereas average concentrations of sum of glucose and fructose in these effluents contributed from 98.6 to $103.8 \%$ to their original concentrations in working standard solutions loaded onto SPE columns. Based on these results, it was concluded that the Dowex $50 \mathrm{~W} \times 8-400$ resin maintains the quantitative retention of $\mathrm{Cu}(\mathrm{II})$ ions $(>97.0 \%)$ and achieves their complete separation from glucose and fructose regardless of the solution flow rate applied. $\mathrm{K}$ and $\mathrm{Na}$ ions were also established to be exhaustively retained by
Dowex $50 \mathrm{~W} \times 8-400$ resin beds in these conditions. Retention efficiencies of $\mathrm{K}$ and $\mathrm{Na}$ for these resins were found to change correspondingly from 99.9 to $100.0 \%$ (K) and from 99.0 to $99.9 \%(\mathrm{Na})$.

\section{Desorption Behavior of Dowex $50 \mathrm{~W} \times 8-400$}

Because the presence of a high concentration of $\mathrm{K}$ and $\mathrm{Na}$ may pose problems in FAAS determinations of $\mathrm{Cu}$ (Pinta 1975), it was expected that the selective elution of these elements (keeping $\mathrm{Cu}$ untouched on resin beds) from SPE columns would be the most favorable. In view of that, the usefulness of 0.2 and $0.5 \mathrm{~mol} / \mathrm{L} \mathrm{HNO}_{3}$ and $\mathrm{HCl}$ solutions used for washing SPE columns and removing $\mathrm{K}$ and $\mathrm{Na}$ ions from resin beds of Dowex $50 \mathrm{~W} \times 8-400$ was evaluated. At first, working standard solutions ( $\mathrm{pH} 4.0)$ were driven through SPE columns at $20 \mathrm{~mL} / \mathrm{min}$. After that, four $10-\mathrm{mL}$ portions of tested $\mathrm{HNO}_{3}$ or $\mathrm{HCl}$ solutions were passed at $2.0 \mathrm{~mL} / \mathrm{min}$ through SPE columns to elute $\mathrm{K}$ and $\mathrm{Na}$ ions. Respective 10-mL portions of column eluates were collected and analyzed on the content of $\mathrm{Cu}, \mathrm{K}$, and Na using calibration with simple water standard solutions. Elution efficiencies (in \%) for $\mathrm{Cu}, \mathrm{K}$, and $\mathrm{Na}$ under these conditions were evaluated relating concentrations of these elements found in respective eluates to their original concentrations in loaded working standard solutions.

As can be seen from Table 3, the best conditions that uphold the total elution of $\mathrm{K}$ and $\mathrm{Na}$ ions from resin beds of Dowex $50 \mathrm{~W} \times 8-400$ and preserve $\mathrm{Cu}$ untouched on SPE columns were achieved with $20 \mathrm{~mL}$ of a $0.5 \mathrm{~mol} / \mathrm{L} \mathrm{HNO}_{3}$ solution. Using this solution, it was possible to elute 
$95.5 \pm 3.7 \%$ of total $\mathrm{K}$ and $97.9 \pm 4.6 \%$ of total $\mathrm{Na}$ retained on SPE columns, whereas $\mathrm{Cu}$ remained preserved. Concentrations of $\mathrm{Cu}$ in all eluates collected were determined to be lower than its DL obtained by FAAS.

Finally, remaining $\mathrm{Cu}$ was stripped from SPE columns with $1.0,2.0,3.0$, and $4.0 \mathrm{~mol} / \mathrm{L} \mathrm{HCl}$ solutions and respective elution efficiencies achieved with these solutions were assessed to select optimum desorption conditions. For that purpose, working standard solutions ( $\mathrm{pH} 4.0$ ) were passed at $20 \mathrm{~mL} / \mathrm{min}$ through resin beds of Dowex $50 \mathrm{~W} \times 8-400$; next, $\mathrm{K}$ and $\mathrm{Na}$ ions were selectively eluted by passing through SPE columns $20 \mathrm{~mL}$ of a $0.5 \mathrm{~mol} / \mathrm{L} \mathrm{HNO}_{3}$ solution at $2.0 \mathrm{~mL} / \mathrm{min}$. Subsequently, $5.0 \mathrm{~mL}$ of a given $\mathrm{HCl}$ solution were passed at $2.0 \mathrm{~mL} / \mathrm{min}$ through resin beds of Dowex $50 \mathrm{~W} \times 8-400$ to recover $\mathrm{Cu}$. Adequate $5.0-\mathrm{mL}$ portions of eluates were collected and concentrations of $\mathrm{Cu}$ were determined in them by FAAS against standard solutions containing corresponding concentrations of $\mathrm{HCl}$.

It was found that, except for a $1.0 \mathrm{~mol} / \mathrm{L} \mathrm{HCl}$ solution, other $\mathrm{HCl}$ solutions provide quantitative recoveries (average values, $n=3$ ) of $\mathrm{Cu}$, i.e., $101.3 \pm 1.8 \%$ in case of a $2.0 \mathrm{~mol} / \mathrm{L} \mathrm{HCl}$ solution, $100.6 \pm 2.8 \%$ in case of a $3.0 \mathrm{~mol} / \mathrm{L} \mathrm{HCl}$ solution, and $94.5 \pm 3.7 \%$ in case of a $4.0 \mathrm{~mol} / \mathrm{L} \mathrm{HCl}$ solution.

Considering all results obtained, it was decided that $20 \mathrm{~mL}$ of a $0.5 \mathrm{~mol} / \mathrm{L}^{\mathrm{HNO}_{3}}$ solution and $5.0 \mathrm{~mL}$ of a $2.0 \mathrm{~mol} / \mathrm{L} \mathrm{HCl}$ solution would be used for the two-step elution in the developed SPE preconcentration/separation procedure. It is worth noticing that Dowex $50 \mathrm{~W} \times 8-400$ is an unspecific resin, and therefore other metal ions, e.g., $\mathrm{Ca}(\mathrm{II}), \mathrm{Fe}(\mathrm{III}), \mathrm{Mg}(\mathrm{II}), \mathrm{Mn}(\mathrm{II})$, and $\mathrm{Zn}(\mathrm{II})$, are quantitatively retained and can be eluted along with $\mathrm{Cu}(\mathrm{II})$ ions (Pohl, Stecka and Jamroz 2012a, 2012b). Under these conditions, it is possible to preconcentrate all of these metals from the honey matrix in a corresponding SPE procedure and determine them by FAAS without any interference resulting from the presence of high amounts of fructose, glucose, $\mathrm{K}$, and $\mathrm{Na}$. In addition, as verified in both cited artilces, the measurements of concentrations of manganese and zinc in the final eluates achieved are free from matrix effects related to the presence of relatively high amounts of calcium and magnesium.

\section{Analytical Characteristics and Application}

Due to lack of an adequate certified reference material for honey, the accuracy of the proposed SPE preconcentration/ separation procedure, as well as the method of the honey analysis, was studied by recovery experiments and the analysis of $10 \%(\mathrm{~m} / \mathrm{v})$ solutions of rape, goldenrod, and heather honeys spiked with known amounts of $\mathrm{Cu}(\mathrm{II})$ ions. $\mathrm{Cu}$ was added to these sample solutions at concentrations
Table 4 Concentrations (in $\mu \mathrm{g} / \mathrm{g}$ ) of $\mathrm{Cu}$ in raw honeys as determined by FAAS after wet ashing of samples with $\mathrm{HNO}_{3}$ and $\mathrm{H}_{2} \mathrm{O}_{2}$ (I) and dissolution of samples in water followed by SPE and two-step elution (II)

\begin{tabular}{llll}
\hline Honey & $\mathrm{I}$ & $\mathrm{II}$ & $C_{\text {-test }}^{\mathrm{a}}$ \\
\hline Acacia & $<0.16^{\mathrm{b}}$ & $0.169 \pm 0.010$ & $\mathrm{NA}$ \\
Goldenrod & $0.444 \pm 0.092$ & $0.418 \pm 0.014$ & +0.329 \\
Heather & $0.358 \pm 0.088$ & $0.274 \pm 0.013$ & +1.335 \\
Lime & $0.330 \pm 0.098$ & $0.259 \pm 0.02$ & +1.017 \\
Multiflower & $<0.16^{\mathrm{b}}$ & $0.186 \pm 0.019$ & $\mathrm{NA}$ \\
Rape & $0.277 \pm 0.087$ & $0.325 \pm 0.024$ & -0.752 \\
\hline
\end{tabular}

$N A$ not applied

Average values $(n=3) \pm$ SDs

${ }^{\text {a }}$ Values of $C$-test calculated for compared mean concentrates obtained after wet ashing and SPE with two-step elution $\left(C_{\text {critical }}\right.$ of 4.303 at the $95 \%$ level of significance)

b Method DL

of $0.005,0.02,0.05,0.10$, and $0.20 \mathrm{mg} / \mathrm{L}$, and this corresponded to $0.10,0.20,0.50,1.00$, and $2.00 \mu \mathrm{g} / \mathrm{g}$ of $\mathrm{Cu}$ in honey samples. Recoveries achieved (average values, $n=3$ ) were found to be within $94.7-97.1 \%$ (at $0.10 \mu \mathrm{g} /$ g), 93.6-98.8\% (at $0.20 \mu \mathrm{g} / \mathrm{g}$ ), $97.3-\mathrm{o} \quad 101.2 \%$ (at $0.50 \mu \mathrm{g} / \mathrm{g}$ ), $96.9 \%$ to $102.4 \%$ (at $1.00 \mu \mathrm{g} / \mathrm{g}$ ), and $97.8 \%$ to $100.2 \%$ (at $2.00 \mu \mathrm{g} / \mathrm{g}$ ), respectively, which proves the good accuracy of this procedure. The method DL for $\mathrm{Cu}$ as assessed with FAAS and the SPE preconcentration/ separation procedure was $3.6 \mathrm{ng} / \mathrm{g}$. It referred to the absorbance of $3 \times \mathrm{SD}$ of mean measurements of respective procedural blanks, i.e., $100-\mathrm{mL}$ working standard solutions with $20 \mathrm{mg} / \mathrm{L}$ of K, $5.0 \mathrm{mg} / \mathrm{L}$ of $\mathrm{Na}$, and $40 \mathrm{~g} / \mathrm{L}$ of fructose and glucose.

To illustrate the suitability of the devised procedure, the SPE preconcentration/separation with the two-step elution was subjected to the analysis of six different raw monoflower and multiflower honeys. Results of this analysis along with results obtained after wet ashing of analyzed honeys are listed in Table 4. As can be seen, the most commonly used in the honey analysis wet-ashing procedure was found to be of low precision and detectability. Relative SDs obtained for the given data set were within 21-31\%. In addition, it was not possible to detect $\mathrm{Cu}$ in acacia and multiflower honeys. In the latter case, the DL of $8.1 \mu \mathrm{g} / \mathrm{L}$ of $\mathrm{Cu}$ was assessed with FAAS in solutions of digested honey samples, and this corresponded to $0.16 \mu \mathrm{g} / \mathrm{g}$ of $\mathrm{Cu}$ in the honey matrix.

By contrast, the proposed SPE preconcentration/ separation procedure allowed measuring $\mathrm{Cu}$ concentrations with the precision (as RSD) in the range of $3-10 \%$ as a result of the determination of 100 time greater concentrations of $\mathrm{Cu}$ compared with those in digested sample solutions. Indeed, according to the $F$-test applied at the $95 \%$ 
level of significance, variances of mean concentrations of $\mathrm{Cu}$ in goldenrod, heather, lime, and rape honeys achieved with the wet-ashing procedure were significantly greater than those obtained with the proposed SPE preconcentration/separation procedure. For that reason, the significance of differences between mean concentrations of $\mathrm{Cu}$ resulted from using both sample preparation procedures was tested using Cochran and Cox test with the critical value $\left(\mathrm{C}_{\text {critical }}\right)$ of 4.303 at the $95 \%$ level of significance (Miller and Miller 2005). No difference between the compared two sets of results was found $\left(\mathrm{C}_{\text {calculated }}<\mathrm{C}_{\text {critical }}\right)$ suggesting that both sample preparation procedures provide statistically indistinguishable results, although the devised SPE preconcentration/separation procedure is approximately four times faster and results in much better precision.

In addition, it was verified that the acidification of prepared honey solutions, performed to dissociate eventual complexes of $\mathrm{Cu}$ with possible organic ligands and release simple $\mathrm{Cu}$ ions, was not necessary. Differences found between results obtained through the analysis of acidified (with $\mathrm{HNO}_{3}$ at $0.1 \mathrm{~mol} / \mathrm{L}$ ) and not acidified solutions of honeys were statistically insignificant according to Student $t$ test performed at the $95 \%$ level of significance. This could be explained by strong interactions of sulphonic functional groups of the strong acidic cation exchanger with possible complexes of $\mathrm{Cu}$ as described previously (Odegard and Lund 1997; Ozdemir and Gucer 1998) or even a mechanical retention of such organic complexes by the gel-type cation exchange resin used here.

\section{Conclusion}

In this study, a sample preparation procedure enabling to enrich traces of $\mathrm{Cu}$ in honey samples and separate this environmentally and toxicologically relevant element from a bulk matrix of fructose and glucose, as well as interferences originating from the presence of $\mathrm{K}$ and $\mathrm{Na}$, has been developed for the FAAS analysis. The proposed procedure combines SPE on a gel-type strongly acidic cation exchanger Dowex $50 \mathrm{~W} \times 8-400$ with two-step elution, in which a $0.5 \mathrm{~mol} / \mathrm{L} \mathrm{HNO}_{3}$ solution was used for the complete elution of $\mathrm{K}$ and $\mathrm{Na}$, whereas a $2.0 \mathrm{~mol} / \mathrm{L} \mathrm{HCl}$ solution was applied to quantitatively recover $\mathrm{Cu}$. This procedure has been established to be a faster and easier alternative to time-consuming and laborious wet ashing of honey samples. The total time investment of this honey pretreatment-including the preparation of resin beds and honey sample solutions, the subsequent resin-based preconcentration, and the sequential elution before FAAS measurements-is approximately three quarters of an hour and approximately 5 times shorter than that required for wet digestion. The use of reagents is also much lower. The method provides precise, accurate, and interference-free determinations of $\mathrm{Cu}$ at the level of $10^{-1} \mu \mathrm{g} / \mathrm{g}$ and could be quite useful for analysts and environmentalists dealing with honey. Using commercially available strong cation exchange sorbent cartridges and vacuum manifolds, it would be possible with the procedure developed to prepare 12-15 honey samples at once.

Acknowledgments The project was funded by the National Science Centre granted under decision no. DEC-2011/01/N/NZ9/00027.

Conflict of interest The authors declare that they have no conflict of interest.

Open Access This article is distributed under the terms of the Creative Commons Attribution License which permits any use, distribution, and reproduction in any medium, provided the original author(s) and the source are credited.

\section{References}

Baroni MV, Arrua C, Nores ML, Faye P, del Pilar Diaz M, Chiabrando GA et al (2009) Composition of honey from Cordoba (Argentina). Assessment of north/south provenance by chemometrics. Food Chem 114:727-733

Bogdanov S (2006) Contaminants of bee products. Apidologie 38:1-18

Bremner I (1998) Manifestations of copper excess. Am J Clin Nutr 67:1069S-1073S

Chudzinska M, Baralkiewicz D (2010) Estimation of honey authenticity by multielement characteristics using inductively coupled plasma-mass spectrometry (ICP-MS) combined with chemometrics. Food Chem Toxicol 48:284-290

dos Santos JS, dos Santos NS, dos Santos MLP, dos Santos SN, de Jesus Lacerda JJ (2008) Honey classification from semi-arid, Atlantic and Transitional Forest zones in Bahia, Brazil. J Braz Chem Soc 19:502-508

Erbilir F, Erdogrul O (2005) Determination of heavy metals in honey in Kahramanmaras city, Turkey. Environ Monit Assess 109:181-187

Fournier E (2005) Mono- and oligosaccharides. In: Wrolstad RE, Acree TE, Decker EA, Penner MH, Reid DS, Schwartz SJ et al (eds) Handbook of food analytical chemistry: water, proteins, enzymes, lipids, and carbohydrates. Wiley, New York

Gaetke LM, Chow CK (2003) Copper toxicity, oxidative stress, and antioxidant nutrients. Toxicology 189:147-163

Grembecka M, Szefer P (2013) Evaluation of honeys and bee products quality based on their mineral composition using multivariate techniques. Environ Monit Assess 185:4033-4047

Hernandez OM, Fraga JMG, Jimenez AI, Jimenez F, Arias JJ (2005) Characterization of honey from the Canary Islands. Determination of the mineral content by atomic absorption spectrometry. Food Chem 93:449-458

Juszczak L, Socha R, Roznowski J, Fortuna T, Nalepka K (2009) Physicochemical properties and quality parameters of herb honeys. Food Chem 113:538-542

Khan MN, Qaiser M, Raza SM, Rehman M (2006) Physicochemical properties and pollen spectrum of imported and local samples of blossom honey from the Pakistani market. Int $\mathrm{J}$ Food Sci Technol 41:775-781

Lachman J, Kolihova D, Miholova D, Kosata J, Titera D, Kult K (2007) Analysis of minority honey components: possible use for the evaluation of honey quality. Food Chem 101:973-979 
Latorre MJ, Pena R, Pita C, Botana A, Garcia S, Herrero C (1999) Chemometric classification of honeys according to their type. II. Metal content data. Food Chem 66:263-268

Madejczyk M, Baralkiewicz D (2008) Characterization of Polish rape and honeydew honey according to their mineral contents using ICP-MS and F-AAS/AES. Anal Chim Acta 617:11-17

Miller JN, Miller JC (2005) Statistics and chemometrics for analytical chemistry. Pearson Education, Harlow

Nanda V, Sarkar BC, Sharma HK, Bawa AS (2003) Physicochemical properties and estimation of mineral content in honey produced from different plants in Northern India. J Food Comp Anal 16:613-619

Nanda V, Singh B, Kukreja VK, Bawa AS (2009) Characterisation of honey produced from different fruit plants of northern India. Int $\mathrm{J}$ Food Sci Technol 44:2629-2636

Odegard KE, Lund W (1997) Multi-Multi-element speciation of tea infusion using cation-exchange separation and size-exclusion chromatography in combination with inductively coupled plasma mass spectrometry. J Anal At Spectrom 12:403-408

Osman KA, Al-Doghairi MA, Al-Rehiayani S, Helal MID (2007) Mineral contents and physicochemical properties of natural honey produced in Al-Qassim region, Saudi Arabia. J Food Agric Environ 5:142-146

Ozdemir Y, Gucer S (1998) Speciation of manganese in tea leaves and tea infusions. Food Chem 61:313-317

Paramas AMG, Barez JAG, Garcia-Villanova RJ, Pala TR, Albajar RA, Sanchez JS (2000) Geographical discrimination of honeys by using mineral composition and common chemical quality parameters. J Sci Food Agric 80:157-165

Pinta M (1975) Atomic absorption spectrometry. Wiley, New York

Pohl P (2009) Determination of metal content in honey by atomic absorption and emission spectrometries. Trends Anal Chem 28:117-128

Pohl P, Sergiel I (2010) Direct determination of the total concentrations of copper, iron and manganese and their fractionation forms in freshly ripened honeys by means of flame atomic absorption spectrometry. Microchim Acta 168:9-15

Pohl P, Sergiel I (2012) Direct analysis of dark honeys for total content of copper and its fractionation forms. Food Anal Methods 5:113-118

Pohl P, Sergiel I, Stecka H (2009) Determination and fractionation of metals in honey. Crit Rev Anal Chem 4:276-288

Pohl P, Stecka H, Jamroz P (2012a) Solid phase extraction and sequential elution for pre-concentration of traces of $\mathrm{Mn}$ and $\mathrm{Zn}$ in analysis of honey by flame atomic absorption spectrometry. Anal Methods 4:125-131

Pohl P, Stecka H, Jamroz P (2012b) Fast and interference free determination of calcium and magnesium in honeys by solid phase extraction followed by flame atomic absorption spectrometry. J Braz Chem Soc 23:710-717

Rashed MN, Soltan ME (2004) Major and trace elements in different types of Egyptian mono-floral and non-floral bee honeys. J Food Comp Anal 17:725-735

Turhan K (2007) Chemical contents and some trace metals of honeys produced in the middle Anatolia region of Turkey. Fresenius Environ Bull 16:459-464

Uren A, Serifoglu A, Sarikahya Y (1998) Distribution of elements in honeys and effect of a thermoelectric power plant on the element contents. Food Chem 61:185-190

Vorlova L, Celechovska O (2002) Activity of enzymes and trace element content in bee honey. Acta Vet Brno 71:375-378

Wieczorek J, Wieczorek Z, Mozolewski W (2006) Can bee honey serve as an environmental marker? Polish J Environ Stud 15:203-207

Yilmaz H, Yavuz O (1999) Content of some trace metals in honey from south-eastern Anatolia. Food Chem 65:475-476

Zukowska J, Biziuk M (2008) Methodological evaluation of method for dietary heavy metal intake. J Food Sci 73:R21-R29 